\title{
Use and safety of conducted electronic devices: what is known?
}

K. Nugent ${ }^{l}$ and C. Cevik ${ }^{2}$

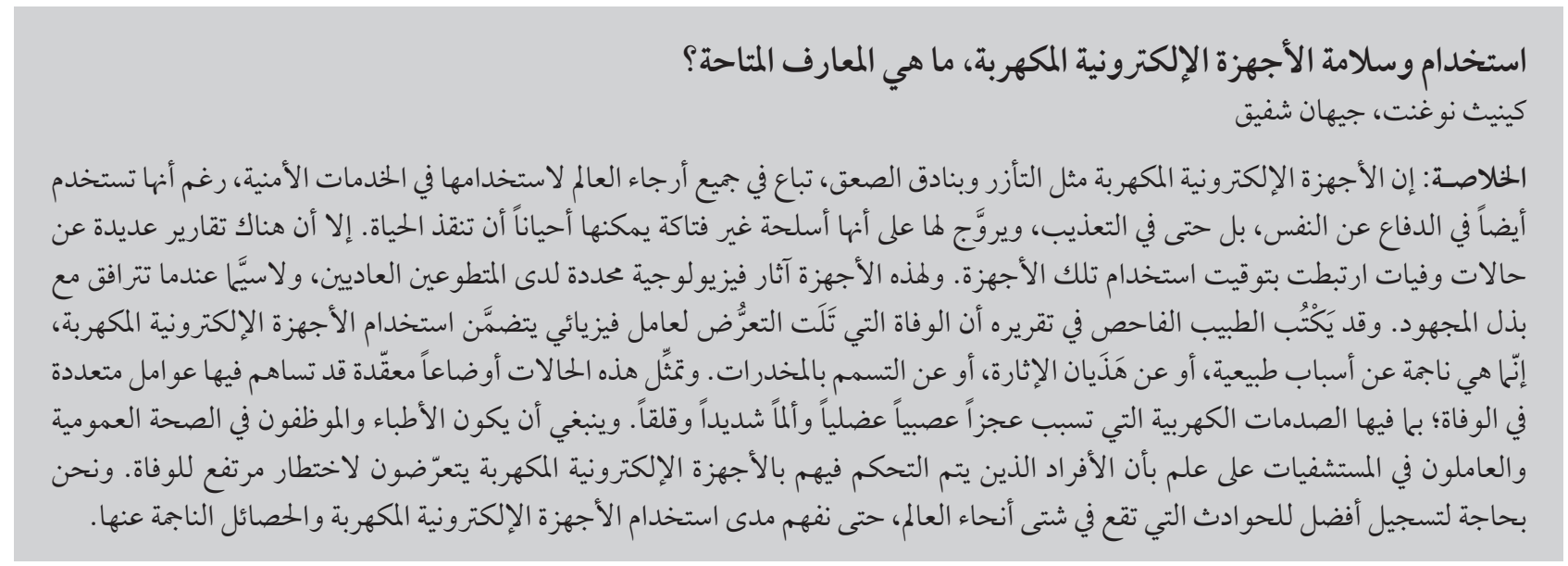

ABSTRACT Conductive electronic devices (CED), such as Taser ${ }^{\circledR}$ and stun guns, are sold worldwide for use by security services, although they have also been used for self-defence and even for torture. CED are promoted as non-lethal weapons which can potentially save lives. However, there are multiple reports of deaths temporally associated with CED use. These weapons have definite physiological effects in normal volunteers, especially when accompanied by exertion. Medical examiners often report that deaths followed physical encounters which included the use of CED were due to natural causes, excited delirium and/or drug intoxication. These cases present complex situations in which multiple factors potentially contribute to the death, including electric shocks which cause neuromuscular incapacitation, severe pain and anxiety. Public health officials, physicians and hospital personnel need to be aware that individuals controlled with CED are at increased risk of death. We need better recording of incidents worldwide to understand the extent and outcomes of CED use.

\section{Utilisation et sécurité des dispositifs à impulsions électriques : quel est l'état des connaissances?}

RÉSUMÉ Les dispositifs à impulsions électriques comme le Taser ${ }^{\circledR}$ et les pistolets à impulsions électriques sont vendus dans le monde entier pour être utilisés par des services de sécurité, mais sont aussi utilisés pour l'auto-défense et même la torture. Ils sont présentés comme des armes non mortelles qui peuvent sauver des vies. Toutefois, de nombreux décès coïncidant avec l'utilisation de ces dispositifs ont été signalés. Ces armes ont des effets physiologiques certains chez des volontaires normaux, en particulier lorsqu'ils sont associés à un effort. Les médecins légistes ont souvent rapporté que les décès suivant des contacts physiques qui comprenaient l'utilisation de dispositifs à impulsions électriques étaient imputables à des causes naturelles, un délire aigu et/ou une intoxication liée à l'utilisation de médicaments et/ou de drogues. Ces cas sont des situations complexes dans lesquelles des facteurs multiples contribuent potentiellement au décès, tels que les chocs électriques à l'origine d'une paralysie neuromusculaire, d'une douleur sévère et d'anxiété. Les responsables de la santé publique, les médecins et le personnel hospitalier doivent être sensibilisés au fait que les personnes neutralisées par des dispositifs à impulsions électriques courent un risque accru de décès. Nous devons améliorer l'enregistrement des incidents dans le monde pour comprendre la portée et les conséquences de l'utilisation des dispositifs à impulsions électriques. 


\section{Patterns of use}

Conductive electronic devices (CED), such as Taser and stun guns, deliver short pulses of high voltage current which cause neuromuscular incapacitation and pain and were introduced as alternatives to lethal weapons. They provide another tool to help police, the military, and other security services to manage dangerous and belligerent subjects $[1,2]$. There are also reports of their use in torture [3-5]. CED are sold worldwide, including the Middle East, and all public health officials and physicians need to know about the potential hazards associated with these devices.

In the United States of America (USA) in 2007 a 56-year-old woman confined to a wheelchair and suffering from schizophrenia called the emergency services to report concerns about possible harm from another family member. Police at the scene eventually "shocked [her] 10 times with Taserguns during a confrontation" for a total of 165 seconds, following which the patient died [6]. This media report provides a stark contrast to the usual promotional material distributed by companies that make CED. For example, the Taser International, Inc. home page lists and updates the total number of lives saved through the use of CED [http://www. taser.com]. Reports collected by the largest manufacturer of these devices in the USA suggest that they have a high level of safety [7], and reports in the medical literature also indicate that the number of deaths associated with CED use is relatively small $[1,8]$. However, investigative journalists and nongovernmental organizations, such as Amnesty International, continue to report a number of deaths associated with CED use [9-11]. The United States Bureau of Justice collects information on deaths of prisoners in custody but does not classify deaths associated with CED into a separate category.

The case described above introduces concerns about the safety of
CED in field use. Web-based searches easily retrieve multiple cases of death associated with the use of CED [9]. In May 2010 Amnesty International reported that more than 390 deaths associated with the use of CED had occurred in the USA since 2001 [10, 11]. These reports support public concerns about CED use and safety and demands for unbiased studies on field use. However, based on our experience with manuscript submissions, some editors and peer reviewers strongly distrust the information provided by Amnesty International but do not specifically enumerate these concerns. Vilke et al. used lists obtained from Amnesty International and the Arizona Republic newspaper to study deaths associated with the use of CED and recovered information on $65 \%$ of the names on the two lists through requests to law enforcement agencies [9]. They made no specific comments that Amnesty International distorted the facts in these cases. We conclude that until more reliable information becomes available through USA government agencies and international agencies, the public and interested investigators must depend, in part, on reports in the print and electronic media to identify case material, and that these reports, in aggregate, raise important concerns about patterns of use of CED in the field.

\section{Do CED have physiological effects in normal subjects?}

In normal subjects CED discharges cause pain in the stun mode and neuromuscular incapacitation through involuntary muscle contraction in the dart mode [2]. In experimental studies these discharges increase the respiratory rate (4 breaths per minute), the tidal volume $(0.5 \mathrm{~L})$, the minute ventilation (13 L/minute) and the lactate level (1.4 mmol) but do not increase the resting heart rate or blood pressure or cause myocardial ischaemia. Applications of CED increase the heart rate for 60 minutes in subjects who have exercised to "near-exhaustion" and increase the secretion of cortisol for 60 minutes and the secretion of adrenaline and noradrenaline for 10 minutes above baseline in resting subjects $[12,13]$. Therefore, the effects of CED discharges depend on the experimental design; they can cause a sustained stress response in some subjects. The question remains: is there any interaction with other stressors during field use?

\section{Population studies and CED-associated mortality}

Medical examiners frequently conclude that subjects who have died after altercations with the police which required the use of CED died from natural causes, drug toxicity and/or excited delirium $[1,8]$. In Bozeman et al.'s 2009 study in the USA two subjects died following CED use. One subject had participated in a prolonged physical struggle with the police and was found to have "dilated cardiomyopathy and cocaine was present in the serum" [8]. The medical examiner did not provide a final cause of death but concluded that the CED was "not causal or contributory to death". This conclusion is extremely important because it allows the proponents of CED to maintain that these devices do not contribute to death in these cases. However, the information provided about this particular case is so limited that it is impossible to decide the cause of death. A National Association of Medical Examiners' position paper outlines strict guidelines for the certification of cocaine-related deaths [14]. These guidelines require a scene investigation, autopsy examination, laboratory analysis and case interpretation. The paper stated that blood and urine levels 
of cocaine do not necessarily directly correlate with toxic effects or explain the cause of death. Some of these cases of cocaine-associated deaths have almost certainly died from other causes but have recently used cocaine. Bertol et al. suggested that brain tissue provides a better source for cocaine determination than postmortem blood and that the mean brain-to-blood ratios of cocaine and benzoylecgomine provide better differentiation between incidental death cases and overdose cases [15]. Therefore, it would seem that the conclusion that cocaine caused the death in these situations requires more effort by medical examiners than simply testing blood for cocaine or other drugs.

The effects of CED may also interact with environmental stressors (especially heat), physical exertion and/ or drug toxicity. Some people exposed to CED have developed a clinical syndrome that resembles the multisystem organ dysfunction/failure seen in acute illness. The Apache scoring system (and others) adds up physiological derangements, including heart rate, respiratory rate, blood pressure, temperature, $\mathrm{pH}$ and laboratory results to predict mortality. In all acute medical disorders, increases in the Apache score increase the mortality above the baseline for the medical condition and age [16]. If CED discharges adversely affect these variables in a person with other disorder(s), such as exertion, cocaine use, and cardiomyopathy, then mortality would be expected to increase. Consequently, it seems to us that conclusions about CED safety in the field are overly simplistic and do not consider the potential interactions with relevant environmental and subject factors.

\section{What is the situation?}

CED are frequently used in dangerous situations and probably help police avoid the use of lethal force. However, many media reports describe the use of CED in situations that do not appear to represent potential harm to the subject, the police or bystanders. For example, it seems very unlikely that the woman described in the second paragraph could harm anyone. CED can cause pronounced neuromuscular incapacitation, sustained tachycardia after exertion, hyperventilation, acidaemia, pain and anxiety, and contribute to the overall stress of the situation $[1,9,13]$. They are lethal weapons in some situations [1]. This is particularly true in subjects who have had prolonged physical encounters with the police, are using cocaine or other sympathomimetic drugs, have heat exposure or have psychiatric disorders [1]. In addition, there are case reports in which CED discharges caused cardiac arrhythmias and excited delirium in the absence of confounding factors $[17,18]$.

We suggest that the USA government and other governmental and nongovernmental organizations need to develop more detailed databases on incustody deaths and make this information available to interested investigators. In particular, Amnesty International, the World Health Organization and other independent organizations need to collect information on CED use patterns and related injuries to determine whether or not there are outcomes in other countries similar to those reported in the USA. These weapons may be used in torture and could help explain the cause of death in some victims. We need more thorough forensic investigations which follow standard guidelines before CED use is exonerated by medical examiners. In particular, in cases where substance use is implicated, drug levels may not provide an adequate explanation for the cause of death. Finally, we need a more integrative analysis by investigators and editors about the interactions among CED, other stresses, medical comorbidity and outcomes.

Competing interests: None declared

\section{References}

1. Nugent $\mathrm{K}$ et al. Conductive energy devices: a review of use and deaths in the United States. Journal of Investigative Medicine, 2011, 59:1203-1210.

2. Pasquier $\mathrm{M}$ et al. Electronic control device exposure: a review of morbidity and mortality. Annals of Emergency Medicine, 2011, 58:178-188.

3. Asfa J. Cairo stun gun boom reflects deepening insecurity [online] (http://Thinkafricapress.com/Egypt/stun-gun-insecurity, accessed 12 April 2013).

4. Welsh J. Electroshock torture and the spread of stun technology. Lancet, 1997, 449:1.

5. Hillman H. Electrical devices used by prison officers, police and security forces. Medicine, Conflict and Survival, 2003, 19:197-204.

6. 56-yr old woman in wheelchair tasered to death by police. newsguru [online] (http://newsguru.newsvine.com/_ news/2007/09/19/971729-56-yr-old-woman-in-wheelchairtasered-to-death-by-police, accessed 20 March 2013).
7. Ho JD et al. Impact of conducted electrical weapons in a mentally ill population: a brief report. American Journal of Emergency Medicine, 2007, 25:780-785.

8. Bozeman WP et al. Safety and injury profile of conducted electrical weapons used by law enforcement officers against criminal suspects. Annals of Emergency Medicine, 2009, 53:480-489.

9. Vilke GM et al. Tactical and subject considerations of incustody deaths proximal to use of conductive energy devices. American Journal of Forensic Medicine and Pathology, 2009, 30:23-25.

10. Fox AW, et al. Conducted energy devices: pilot analysis of (non-) attributability of death using a modified Naranjo algorithm. Forensic Science International, 2012, 223:261-265.

11. United States of America-Amnesty International report 2010 [online] (http://www.amnesty.org/en/region/usa/report-2010, accessed 6 April 2013).

12. Vilke GM et al. Physiologic effects of the Taser after exercise. Academic Emergency Medicine, 2009, 16:704-710. 
13. Ho JD et al. Acidosis and catecholamine evaluation following simulated law enforcement "use of force" encounters. Academic Emergency Medicine, 2010, 17:e60-e68.

14. Stephens BG et al. National Association of Medical Examiners position paper on the certification of cocaine-related deaths. American Journal of Forensic Medicine and Pathology, 2004 25:11-13.

15. Bertol E et al. Cocaine-related deaths: an enigma still under investigation. Forensic Science International, 2008, 176:121-123.
16. Wagner DP, Knaus WA, Draper EA. Statistical validation of a severity of illness measure. American Journal of Public Health, 1983, 73:878-884.

17. Naunheim RS et al. Ventricular fibrillation in a man shot with a Taser. Emergency Medicine Journal, 2010, 27:645-646.

18. Feeney $\mathrm{C}$ et al. Acute agitated delirious state associated with Taser exposure. Journal of the National Medical Association, 2010, 102:1254-1257. 